\title{
THE EFFECT OF MULTILATERALISM, REGIONALISM, AND OPEN REGIONALISM TOWARDS EXPORTS: ASEAN-5 STUDY CASE
}

\author{
Mawar Winona Lubis*1 \\ ${ }^{1}$ Economy Department, Parahyangan Catholic University, Indonesia
}

\begin{abstract}
Conceptually elimination or reduction of trade barriers through a Regional Trading Arrangement would increase export and import in the region. Trade diversion would take effect and make member countries buy each other goods and services that become cheaper. Open regionalism is another regionalism concept in which the parties involved promise to extend lower tariffs concession not only to member countries but also to other trading partners. This will hinder member countries to reap the benefit of trade diversion. This study examines the effect of Regionalism (after AFTA was fully effective) and Open Regionalism (after Open Regionalism was fully effective for more developed APEC members) on ASEAN-5 countries' export. Using ARIMAX model, the results show that regionalism has a significant yet negative effect on Malaysia and The Philippines and a positive significant effect on Singapore, whereas it is not significant for Indonesia and Thailand's exports. Open regionalism is shown to be not significant for Indonesia, Thailand, and The Philippines exports but it has a negative significant impact for Singapore and Malaysia's exports.
\end{abstract}

Keywords: Trade, Export, Regionalism, Open Regionalism, Multilateralism, ASEAN

JEL: F55, F15

\section{ARTICLE INFO}

Received: September $30^{\text {th }}, 2016$ Revised: November 20 ${ }^{\text {th }}, 2016$

Accepted: November $26^{\text {th }}, 2016$

Online: December $24^{\text {th }}, 2016$

*Correspondence: Mawar Winona Lubis

E-mail:

mwinonalubis@gmail.com

To cite this document: Lubis, M.W. (2016). The Effect of Multilateralism, Regionalism, and Open Regionalism Towards Exports: ASEAN-5 Study Case. JDE (Journal of Developing Economies), 1(2), 76-88

\section{Introduction}

Jayanthakumaran \& Sanidas (2007), stated that multilateralism can raise openness of trade while regionalism could impede openness of trade; therefore, the exports and GDP value of a country could be affected by it. It is also said that if a country tends more into participating in a multilateral cooperation than in a regional cooperation the possibilities of economic growth will be greater compared to if a country tends more into participating in a regional cooperation. From the above proposition, a regional cooperation will not ultimately give much impact on the member countries' exports. On the other hand, regional cooperation have shown to help avoiding conflict among its members and also help keeping a stable economy among the members, with results of a more facilitated trade system in the region. Open regionalism could give combined benefits from multilateralism and regionalism, although its non-binding principles could lead to a low-enforced trading system. Jayanthakumaran \& Sanidas (2007) also found that international trade cooperation/pacts can significantly raise the value of exports and GDP of a country indirectly through foreign investment and other eco-

JDE (Journal of Developing Economies) p-ISSN: 2541-1012; e-ISSN: 2528-2018

DOI: http://dx.doi.org/10.20473/jde.v1i2.3293

Open access under a Creative Commons Attribution 4.0 International

(CC-BY) 
nomic activities beside export and import. If we look at regionalism, both trade creation and trade diversion can actually happen.

Trade creation in regionalism would be the moment when a country would decide to trade a certain commodity with a country (member of RTA) that has higher production efficiency than the domestic producers Trade diversion in regionalism happens when non-member countries who are more efficient in producing a certain commodity cannot compete with member countries due to lower import tariff among member countries of a Regional Trading Arrangement. These conditions do not supposedly happen in multilateralism as all countries should validate the MFN status to all countries, and trade creation would be a condition where opportunities of expanding trade for all countries would be equal, only depending on the production efficiency of every individual country.

Tariffs reduction in AFTA is done through Common Effective Preferential Tariffs (CEPT) mechanism. Through this mechanism, tariff rates are gradually reduced to $0 \%-5 \%$ level. CEPT was completed in year 2002 for ASEAN-6 countries and therefore AFTA can be said to be fully effective for ASEAN-6 in 2003. AFTA is expected to boost intra ASEAN trade and makes ASEAN member countries more attractive to foreign investors. On the other hand, the discriminative nature of Regional Trading Arrangement might shun external trade. The net effect will depend on whether intra trade could outweigh the possible reduction of external trade.

In contrast to regionalism, the trading system in open regionalism would facilitate trade creation conditions as in multilateralism, because open regionalism would set same trading tariffs to non-member countries. So far APEC is the only Regional Trading Arrangement that follows this rule. For AFTA members which are also APEC members, other APEC non-ASEAN member countries will not treat ASEAN members more favorably (in the sense of giving more favorable tariff rates) as in ASEAN. The lower tariff rates given to ASEAN APEC members are also given to non-APEC members. Thus, exported goods from ASEAN members will compete on equal ground with other non-ASEAN export in APEC non-ASEAN markets. The open regionalism principle has been fully effective in advanced APEC member countries such as the US, Canada, Japan, Australia and New Zealand since 2010. Will the membership of APEC affect total export of ASEAN 5 positively or negatively depends on whether ASEAN products have strong competitive advantage in advanced APEC members' markets and this competitiveness might differ from one country to another.

There has been some research regarding the impact of Regional Trading Arrangement on trade or export. Romalis (2004), examines the effect of NAFTA and CUSFTA on international trade, in which he finds that both NAFTA and CUFSTA have had a significant impact on trading volumes internationally, and also increasing North American output and prices in highly protected sectors by excluding or pushing out imports from the non-member countries.

De Azevedo (2002) studies the effect of MERCOSUR on its members intra-trade volume and find that it is not affected by the creation of trading blocs or regional cooperation, although the overall exports and imports of each member country has been influenced by the establishment of Mercosur. Another study by López (1994) state that NAFTA did not help Mexico's economy growth, as NAFTA was not able to raise exports and instead increasing the country's import volume. This research aims at examining the effect of regionalism (after AFTA was fully effective) and open regionalism (after APEC became fully effective for its developed member countries), compared to the multilateral regime (when WTO and GATT rules was applied) on ASEAN-5 exports. 


\section{Literature Review \\ ASEAN}

One of the trading agreements that have been conducted by the ASEAN countries is the ASEAN Free Trade Area (AFTA) Agreement signed on 28 January, 1992. In AFTA, trade is liberalized gradually through a scheme called Common Effective Preferential Tariff (CEPT). In this scheme tariffs among ASEAN member countries are gradually reduced to $05 \%$ level.

ASEAN 6 countries were targeted to reach this tariff level for all commodities in the end of 2002, while the CLMV were given more time until 2006. Such tariff setting is what causes the argument of how regionalism is often discriminative, since supposedly member countries would prefer to trade among the other member countries due to lower tariff. The determination of tariffs done in the AFTA scheme can therefore trigger trade diversion. This does not mean that AFTA members will trade only with other AFTA members. In fact, one important aspect that needs to be highlighted for ASEAN is that their main trading partners aren't the members themselves but other countries such as The United States and China (Hastiadi, 2011).

\section{Multilateralism under GATT and WTO}

The WTO has a few principles which can show how multilateralism can lead trade creation to happen. Some of those principles which increases trade creation are among others the non-discriminative principle, transparency principle, and raising trade competitiveness. The non-discriminative principle prohibits the WTO members to apply trading regulations which favor certain countries only. That condition is achieved by giving the Most Favored Nation (MFN) status to all WTO members. The transparency principle of the WTO means that all member countries have to report all of their trading activities, trading regulations and policies to the WTO. This is meant to avoid violations being made such as in setting a trading regulation or a tariff not according to the agreements. Raising trade competitiveness among member countries is something that the WTO wants to achieve in order to lower all kinds of trading activities that could disadvantage trading partner countries, or in other words to remove unfair trading regulations (WTO, 2015).

The majority of the ASEAN member countries are members of the WTO. The regulations which are set by the WTO are automatically followed by the ASEAN member countries and therefore through this they have access to non-ASEAN trading as well. Therefore, it needs to be reminded that although ASEAN has its own trading regulations, they still have to follow trading regulations agreed in the WTO.

\section{Open Regionalism \& APEC}

Open regionalism is differed from regionalism due to one aspect which is its non-discriminative trading principles. It was clearly stated in the Bogor Conference in 1994, that trade liberalization through APEC should not only benefit its member countries but also nonmember countries. Open regionalism can be defined as a form of multilateralism which depends on the establishment of trading blocs, in which according to Hormats (1994), the existence of trading blocs has actually helped economic growth in many countries. As open regionalism strives to build non-discriminative trade by setting the equal tariffs for members and as well as non-members, open regionalism could be not as benefitting as other forms of regional cooperation. The equality of tariffs could lead to higher level of trade competition where the not sufficiently efficient economies would be disadvantaged by trade creation. 
APEC does not mainly focus on trade but also deals with other economic activities and issues. The main pillars of APEC's agenda focus on are:

1. Trade and investment liberalization

2. Business facilitation

3. Economic and technical cooperation (ECOTECH)

These pillars show how open regionalism could be a mix of multilateralism and regionalism. Trade and investment liberalization is done through APEC by primarily lowering both tariff and non-tariff barriers. APEC also tries to facilitate business activities throughout the Asia-Pacific region by reducing the time, cost, and uncertainties. ECOTECH is connected to facilitation of trade as it focuses on cooperation to build infrastructures and other technologies (APEC, 2016).

It is seen that APEC does focus on its member economies, but since they are against trade discrimination, barriers of trade are lowered even for non-member trading partner countries. It can be said that the benefits of APEC membership on trade would be left to the cooperation besides tariff reduction, such as the ECOTECH. As ASEAN-5 are also members of APEC, lower tariff concession given to them by the more advanced APEC members such as the USA and Australia, will also be given to non-APEC members trading with these advanced countries. In that way, ASEAN-5 products will compete fairly with no more favorable terms with non-APEC members so that trade diversion cannot occur.

\section{Issues in an international economic cooperation}

International economic cooperation in whatever forms undoubtedly give benefits to their members. But each type of cooperation also carries within it some problems related to the form of cooperation it takes. Multilateral cooperation like the WTO (GATT previously) seemed to run smoothly at the beginning. Rounds of discussion it held could be completed successfully although they took years to complete, until the last round (Doha round) which started in 2001. There are many reasons why it stagnates; too many agenda, difficult agenda and most of all, the large number of country representatives with different interest. According to Arcas (2011), multilateral cooperation faces more problems as the number if member countries are usually much larger than regional cooperation.

Problems in a regional cooperation, how it is seen in ASEAN which has member countries with different economic condition also find difficulties to achieve a form of agreement. The main reason why it is hard for ASEAN to reach agreements is that its "ASEAN Way" principle of not interfering with other member countries' domestic issues makes it hard for the member countries to reach a political or economic harmonization. This is one of the reasons why ASEAN did not go through the customs union stage of regionalism as entering a customs union requires a harmonization of certain trading policies. It is also said that regional agreements can be said to be frequently asymmetric where the system would disadvantage some countries (Arcas, 2011).

The problems found in implementing open regional regulations can also be found. As open regionalism's regulations are not very binding due to their non-discriminative trading principles with non-member countries, it could be found not very benefitting to certain countries. For countries who does not have a goal to liberalize their trade any further in their agenda might find that the MFN status could be too heavy to be reciprocated at. Therefore, for those countries that are trying to protect and liberalizing is not possible, open regionalism 
could be undesirable (Garnaut, 2004). At the same time, countries who want trade liberalization could face higher competition among members and non-members and become a victim of trade diversion. Although by looking at the fact that no country has ever left from APEC show that having its membership might give certain economic benefits unrelated to trade or the economy at all. One of the main problems faced by APEC is the fact that most members are not keen or interested in building stronger open regional relations as they have their own regional cooperation, such as the ASEAN countries. As an addition, the other Asian countries such as China, Japan, and India have already established bilateral cooperation with ASEAN countries, and all their agenda might contradict APEC's regulations and principles. APEC has also failed to define open regionalism which impacts the implementation of the trading system. Besides, trade issues among member countries involved in agriculture, anti-dumping, and Uruguay Round agreements became obstacles for APEC to reach an agreement of their own (Park, 2002).

\section{Methodology}

In order to find the results of this research, the ARMA model is used to regress a certain variable to its own past values. Since a few exogenous variables are added in the model, the model is called ARMAX model. The sample of this study consists of ASEAN-5 countries, namely: Indonesia, Malaysia, Singapore, The Philippines, and Thailand, observed from 1980 to 2014 (World Bank, 2015). Brunei Darussalam, Cambodia, Laos, Myanmar and Vietnam are not included in the sample as these countries joined ASEAN after 1980. Besides that, the ASEAN-5 countries are also members of APEC and the WTO. To look at how multilateralism, regionalism, and open regionalism affects ASEAN-5's exports, two Dummy variables representing Regionalism and Open regionalism are added to the model. Regionalism is regarded to have been started since 2003 when CEPT in AFTA was fully effective for ASEAN- 6 countries while Open Regionalism for these countries started in 2010 when APEC's MFN rule has become fully effective for the advanced APEC member countries.

Before the ARIMA models are determined, the stationarity of the variables should be tested using the Augmented Dickey-Fuller test. Afterwards, the correlograms of stationary variables are used to find the proper lags for its AR and MA model. Once the exogenous variables are included in the model, a Augmented Dickey-Fuller test is used again for residual diagnostics to justify whether the adequacy of the model is passable to be used for further interpretation and forecasting.

The variables which are exogenous can be included into the ARIMA model, so that the model will become an ARMAX model. The standard ARMAX model is as follows:

$$
\begin{aligned}
\Delta Y_{t}= & \beta_{0}+\beta_{1} \Delta Y_{t-1}+\beta_{2} \Delta Y_{t-2} \ldots \ldots \ldots+\beta_{p} \Delta Y_{t-p}+\varepsilon_{t}-\gamma_{1} \varepsilon_{t-1}- \\
& \gamma_{1} \varepsilon_{t-2} \ldots \ldots \ldots-\gamma_{q} \varepsilon_{t-q}+\delta_{1} X_{1 t}+\delta_{2} X_{2 t}
\end{aligned}
$$

This study uses the ARMAX model as following:

$$
\begin{aligned}
\text { Export }_{t}= & \beta_{0}+\beta_{1} \Delta \text { Export }_{t-1}+\beta_{2} \Delta \text { Export }_{t-2} \ldots \ldots \ldots+\beta_{p} \Delta \text { Export }_{t-p}+\varepsilon_{t}-\gamma_{1} \varepsilon_{t-1}- \\
& \gamma_{2} \varepsilon_{t-2} \ldots \ldots \ldots-\gamma_{q} \varepsilon_{t-q}+\delta_{1} \text { DRegionalism }_{t}+\delta_{2} \text { DOpenregionalism }_{t}
\end{aligned}
$$

Where:

Export

Regionalism

Open regionalism
= Export value (as a percentage of GDP) from 1980-2014.

$=$ Regional dummy regime from 2003-2014.

= Open regional dummy regime from 2010-2014. 


\section{Research Object}

The object of this research are the export values of the ASEAN-5 countries which are Singapore, Indonesia, Malaysia, Thailand, and The Philippines from 1980-2014. In this section the levels of export of each country will be explained.

\section{Indonesia}

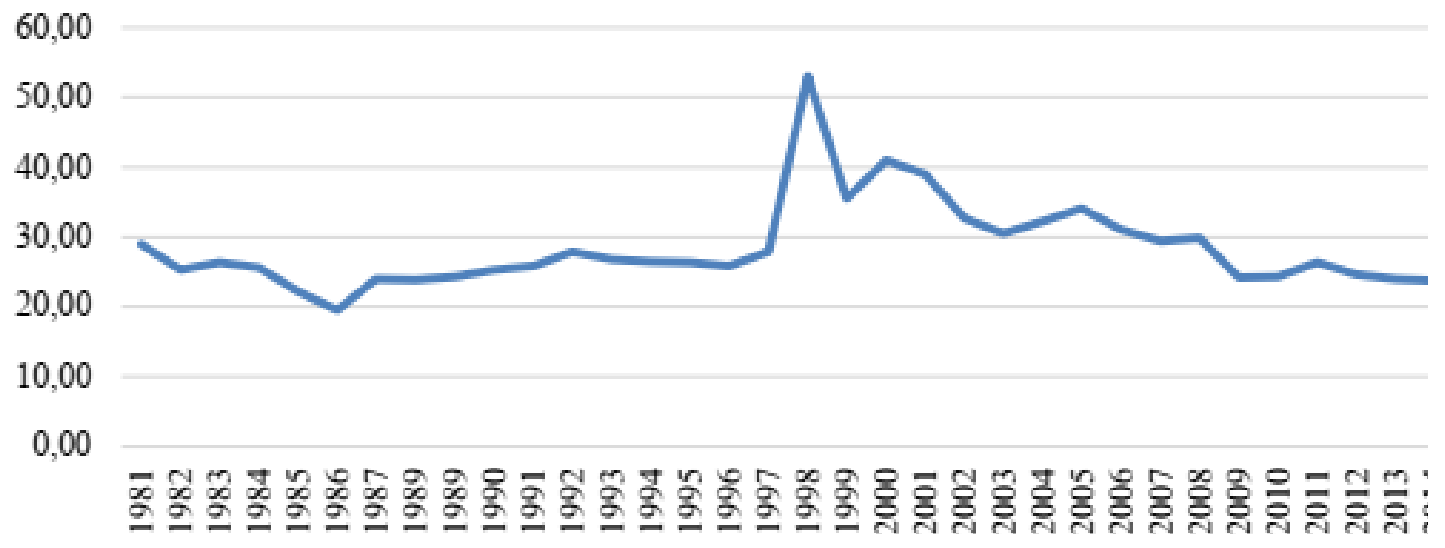

Figure 1: Exports (\% of GDP) of Indonesia (1981-2014)

It is shown that Indonesia's exports rise throughout the period and fall again later on. Indonesia has been one of the ASEAN and also one of the world's largest oil exporters. Besides oil and other minerals being its main exporting commodity, Indonesia also globally exports its agriculture like most of the ASEAN members. It is seen that there is a peak for the year of 1989 as the result of Indonesia's government heavy exploitation of its mineral resources as a program to boost the country's export values and its role in international trade among the advanced countries. Since then exports' contribution towards the country's economic growth has become more visible, although it can be seen that it fell throughout the years until currently due to the global financial crisis which lowered overall international trade. As a result, currently Indonesia is one of the largest global oil suppliers. Like most ASEAN countries that whose economies weren't heavily affected by the financial crisis in 2008, Indonesia's exports were cut due to its trading partners facing a greater impact from the crisis making their import demands lesser than usual. It is seen in the years of 19981999 Indonesia faced an increase of exports. This is due to the Asian financial crisis in which devastated the country's economy, making other countries more attracted into importing cheaper goods from Indonesia.

\section{Malaysia}

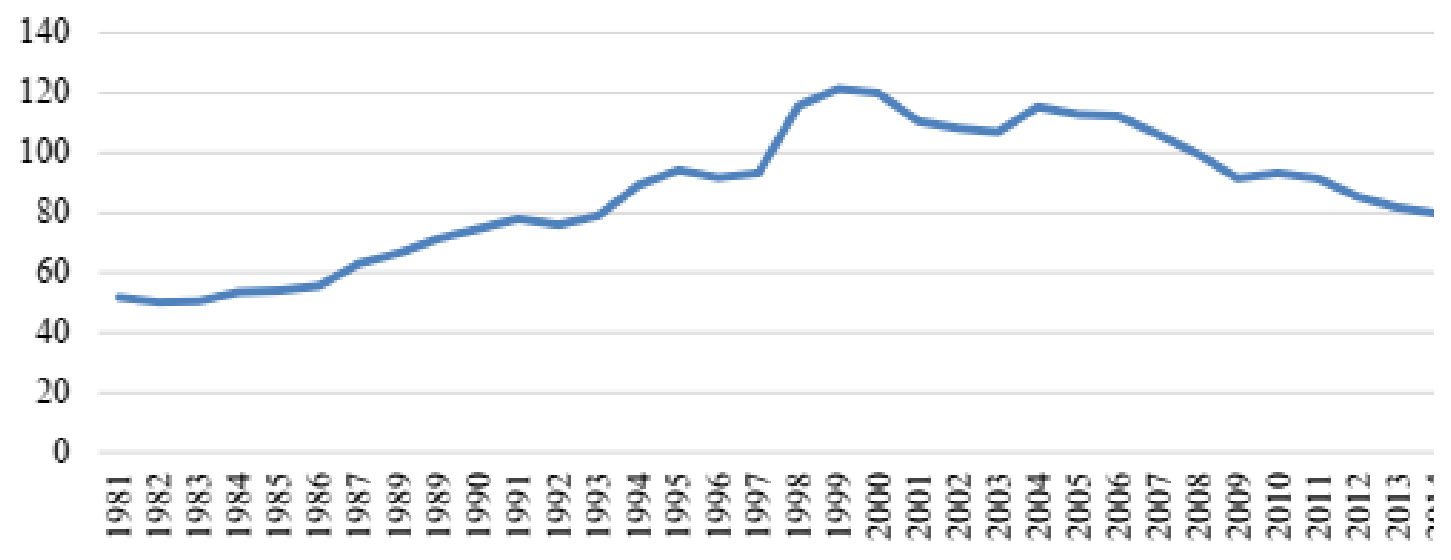

Figure 2: Exports (\% of GDP) of Malaysia (1981-2014) 
Malaysia's largest trading partner is China and has become China's leading ASEAN trading partner since 2008. This condition helped Malaysia in keeping their export value more stable during the 2008 global financial crisis. The bilateral trading cooperation between the two countries is growing stronger, which ensures Malaysia's exporting activities with the fast-growing economy of China. Malaysia's main export goods are oil and crude oil, making the country a competitor with Indonesia and Singapore in oil supply among the ASEAN countries as well as globally. Still, although both Malaysia and Indonesia have a much larger supply of mineral resources, Singapore leads in certain oil exports as it is able to provide higher-technology processed minerals and oils compared to its ASEAN counterparts. Similar conditions can be seen during the Asian financial crisis era during 1998-1999 where Malaysia's exports increased as a result from non-Asian countries attracted to trade with Asian countries facing economic struggles.

\section{Singapore}

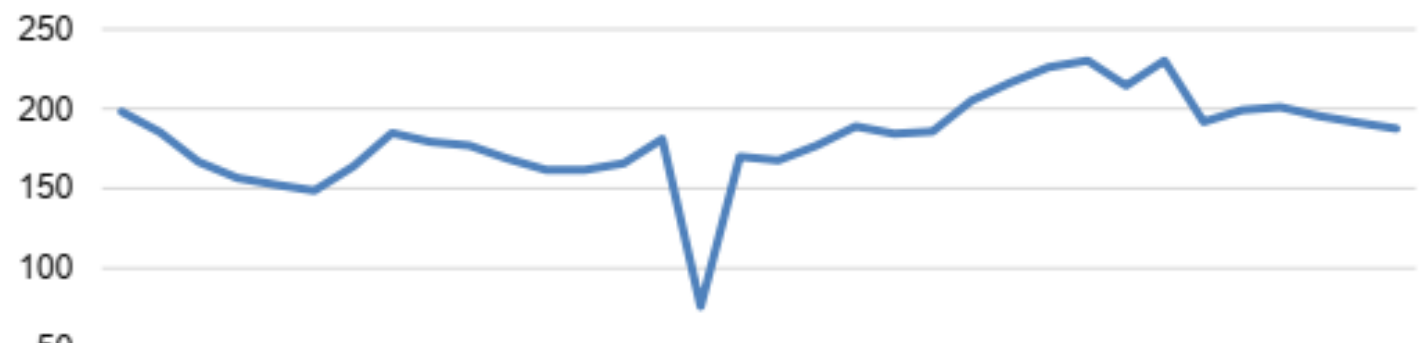

50

0

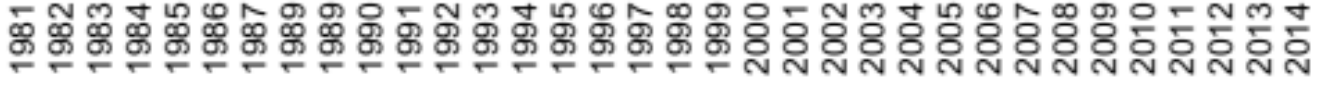

Figure 3: Exports (percentage of GDP) of Singapore (1981-2014)

All of the ASEAN countries experience a rising value of exports, with Singapore being the leading ASEAN member in its total export value. Singapore has taken a very open approach to trade liberalization, which helped the country into boosting its economy. It can be seen from the value above that the portion of Singapore's exports towards its GDP is highest compared to the other ASEAN countries. Singapore also holds a large portion of specialized human resources in the ASEAN region which makes Singapore highly competitive. Singapore's exports declined in 2009 that may be the result of the global financial crisis. Although most of the ASEAN countries did not experience a relatively heavy recession, the economies of trading partner countries around the world experienced a larger loss. It can be seen that in the year of 2008-2010, most ASEAN countries experienced a decline in their exports as well caused by the global financial crisis. During the Asian financial crisis in 1998-1999, Singapore's exports experienced a decline as its whole economy was heavily affected by the crisis.

\section{Thailand}

Similar to Indonesia. Thailand's exports increased in the year of 1998-1999 due to the Asian financial crisis, which attracted other countries who weren't affected (such as the U.S.A. and European countries) to make trading activities with ASEAN countries. This is due to the lower prices when importing from countries who are facing economic crisis and gaining more profit when exporting. The fast economic recovery from the 1998 crisis achieved by most of the ASEAN countries helped Thailand to establish stronger export growth, aiming China and the United States as its main exporting partner. Thailand's bilateral trading agreements with 
China involving agricultural goods in 2002, Australia in 2005, and India in 2003 may contribute to the growth of its export value.

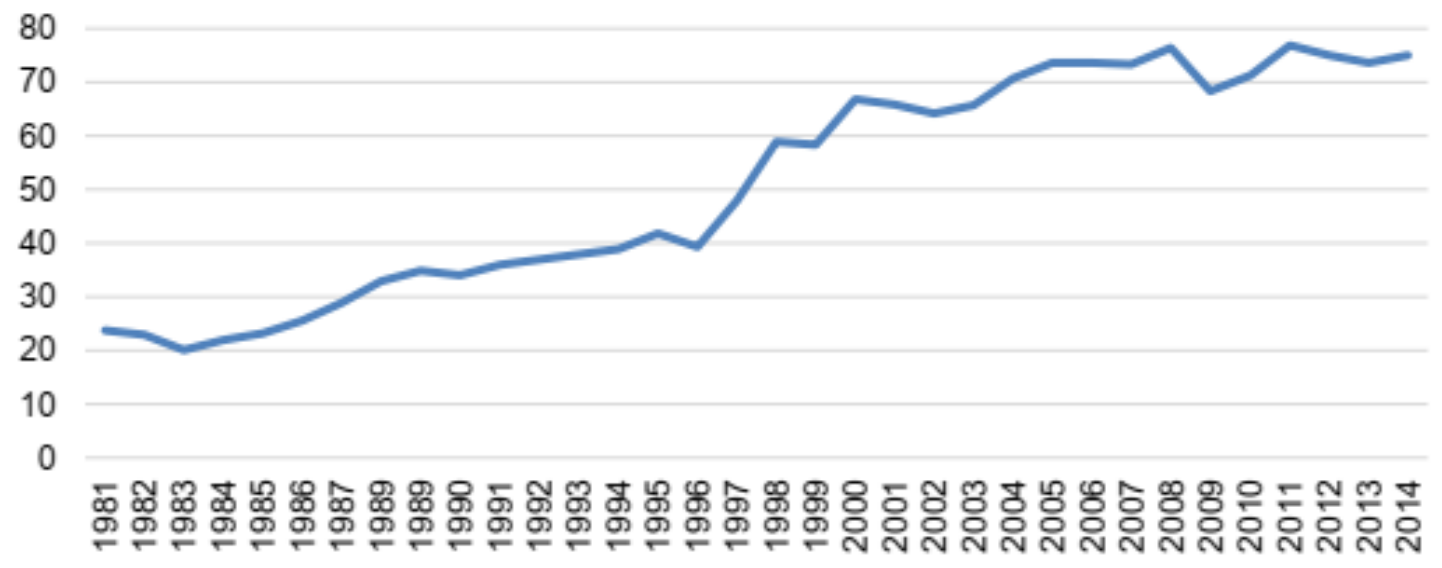

Figure 4: Exports (\% of GDP) of Thailand (1981-2014)

Philippines

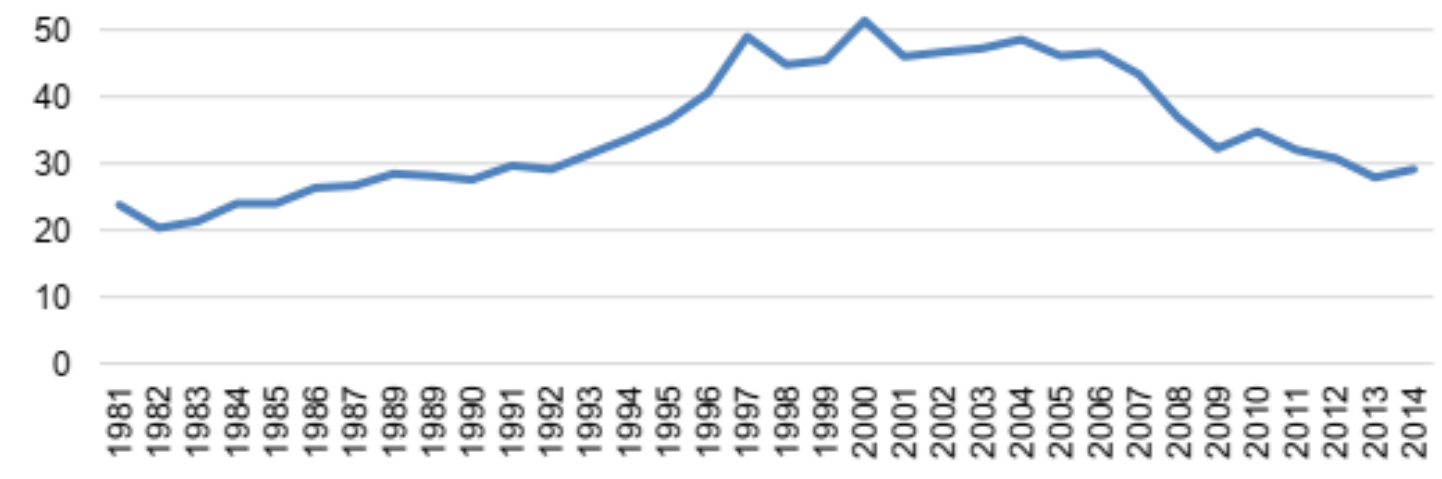

Figure 5: Exports (\% of GDP) of The Philippines (1981-2014)

The Philippines' main export good is different from its ASEAN-5 partners. The country exports a large amount of electronical goods such as integrated circuits, analogue and hybrid computers, and diodes, all involved in computing/computer parts. Like most of the ASEAN-5, its exports are mainly destined to China as its largest trading partner, and other advanced countries such as Japan and the United States. Since most of its main exporting goods are different from its neighboring countries, The Philippines hold comparative advantage to many of the goods the country produces. Just like the other ASEAN-5 members, The Philippines' export rise during the Asian financial crisis in 1998-1999, and by the time it had become stable it declined by 2006 following the global financial crisis in 2008.

Results and Discussion

Table 1: Results of Augmented Dickey-Fuller Test for ASEAN-5 Countries

\begin{tabular}{llccccc}
\hline & Level & & \multicolumn{3}{c}{ First Difference } \\
\hline & t- tatistic & P-value & stationarity & t- tatistic & P-value & stationarity \\
\hline Indonesia & $-1,681719$ & 0,4296 & $\begin{array}{c}\text { non-station- } \\
\text { ary }\end{array}$ & $-3,159042$ & 0,0335 & stationary \\
\hline
\end{tabular}




\begin{tabular}{|c|c|c|c|c|c|c|c|c|c|c|c|}
\hline & \multicolumn{5}{|c|}{ Level } & \multicolumn{6}{|c|}{ First Difference } \\
\hline & \multicolumn{2}{|l|}{ t- tatistic } & \multicolumn{2}{|l|}{ P-value } & stationarity & \multicolumn{3}{|c|}{ t- tatistic } & P-value & \multicolumn{2}{|r|}{ stationarity } \\
\hline Singapore & \multicolumn{2}{|l|}{$-1,483672$} & \multicolumn{2}{|l|}{0,5275} & $\begin{array}{c}\text { non-station- } \\
\text { ary }\end{array}$ & \multicolumn{3}{|c|}{$-3,166249$} & 0,033 & \multicolumn{2}{|r|}{ stationary } \\
\hline Malaysia & \multicolumn{2}{|l|}{$-2,134979$} & 0,233 & & $\begin{array}{c}\text { non-station- } \\
\text { ary }\end{array}$ & \multicolumn{3}{|c|}{$-3,31709$} & 0,0227 & & stationary \\
\hline Thailand & \multicolumn{2}{|l|}{$-1,384191$} & \multicolumn{2}{|l|}{0,5775} & $\begin{array}{c}\text { non-station- } \\
\text { ary }\end{array}$ & \multicolumn{3}{|c|}{$-4,420507$} & 0,0015 & & Stationary \\
\hline \multirow[t]{18}{*}{$\begin{array}{l}\text { Philip- } \\
\text { pines }\end{array}$} & \multicolumn{2}{|l|}{$-1,992042$} & \multicolumn{2}{|l|}{0,2887} & \multicolumn{2}{|c|}{$\begin{array}{c}\text { non-station- } \\
\text { ary }\end{array}$} & \multicolumn{2}{|c|}{$-3,262809$} & 0,0257 & \multicolumn{2}{|r|}{ stationary } \\
\hline & \multicolumn{2}{|c|}{ Autocorrelation } & Part & al Cor & rrelation & & $\mathrm{AC}$ & PAC & Q-Stat & Prob & \\
\hline & ᄃ & 1 & & $\square$ & 1 & 1 & -0.332 & -0.332 & 3.9678 & 0.046 & \\
\hline & 1 & 1 & & 1 단 & 1 & 2 & -0.005 & -0.129 & 3.9689 & 0.137 & \\
\hline & & 1 & & 17 & 1 & 3 & 0.100 & 0.063 & 4.3534 & 0.226 & \\
\hline & 1 & 1 & & 1 & 1 & 4 & -0.081 & -0.028 & 4.6171 & 0.329 & \\
\hline & । 口 & 1 & & $1 \square$ & I & 5 & -0.131 & -0.182 & 5.3246 & 0.378 & \\
\hline & 1 & 1 & & 1 & 1 & 6 & 0.084 & -0.043 & 5.6286 & 0.466 & \\
\hline & I & I & & 1 & $\sqsupset 1$ & 7 & 0.102 & 0.139 & 6.0864 & 0.530 & \\
\hline & 1 & I & & 1 & $\sqsupset 1$ & 8 & 0.002 & 0.131 & 6.0866 & 0.638 & \\
\hline & 1 & 1 & & 14 & 1 & 9 & -0.103 & -0.106 & 6.6002 & 0.679 & \\
\hline & 1 & 1 & & 1 & 1 & 10 & 0.109 & -0.005 & 7.1994 & 0.706 & \\
\hline & 1 & 1 & & 10 & 1 & 11 & 0.009 & 0.098 & 7.2032 & 0.782 & \\
\hline & $\square$ & 1 & & $1 \square$ & 1 & 12 & -0.283 & -0.222 & 11.604 & 0.478 & \\
\hline & 1 & 1 & & 1 든 & 1 & 13 & 0.088 & -0.161 & 12.055 & 0.523 & \\
\hline & 1 & 1 & & 14 & 1 & 14 & -0.014 & -0.105 & 12.066 & 0.601 & \\
\hline & 10 & 1 & & 11 & 1 & 15 & -0.051 & -0.011 & 12.231 & 0.661 & \\
\hline & 1 다 & 1 & & $1 \square$ & 1 & 16 & -0.112 & -0.214 & 13.082 & 0.667 & \\
\hline
\end{tabular}

Figure 6: Correlogram of Indonesia

As an example for looking at the correlogram, above shows the correlogram for Indonesia's export variable where both the autocorrelation function and the partial correlation function are exponentially decayed, showing that Indonesian exports is not just AR or MA, but ARMA or ARIMA $(p, 1, q)$ because the variable is already first differenced. The value of $(p, q)$ is determined after the exogenous variables are entered into the model.

After entering the exogenous variables, the followings are the predicted best model for each country's export variable.

$$
\begin{array}{ll}
\text { Indonesia } & =\operatorname{ARIMA}(1,1,1) \\
\text { Singapore } & =\operatorname{ARIMA}(0,1,1) \\
\text { Malaysia } & =\operatorname{ARIMA}(2,1,1) \\
\text { Thailand } & =\operatorname{ARIMA}(1,1,1) \\
\text { Philippines } & =\text { as a random walk variable or } \operatorname{ARIMA}(0,1,0)
\end{array}
$$

\section{Indonesia}

Indonesia's membership to ASEAN, just like any of its other ASEAN counterparts is supposed to benefit its exports as regionalism is supposed to be discriminative for the ASEAN non-members. It is seen from the table above that regionalism dos not have a significant effect on Indonesia's exports, with a negative relationship. Therefore, it can be said that regionalism 
does not affect Indonesia's exports compared when the multilateral regime still prevailed in Indonesia's trading system. When import tariffs are zero or close to zero in ASEAN region, products can be traded with lower prices in this area. The fact that Indonesia's export declines might have occurred due to Indonesia's lower trading competitiveness compared to the other ASEAN member countries, in terms of productivity, price, and other aspects. The probability value of the open regionalism dummy variable in the regression shows that it does not have a significant effect on Indonesia's exports. This indicates that Indonesia's membership to APEC does not significantly change its export values compared to when only the multilateral trading system existed. The involvement of Indonesia in open regionalism was thought to be not beneficial to Indonesia because it has to compete with non-APEC countries in the APEC developed countries' market. The fact that it does not change Indonesia's export could mean that the open regionalism rule has not been effectively applied or Indonesia's export are different from APEC's developed nations' import from their non-APEC trading partners.

Table 2: Results of ARMAX Model Regression for ASEAN-5 Countries Exports

\begin{tabular}{|c|c|c|c|c|c|c|}
\hline & & Indonesia & Singapore & Malaysia & Thailand & Philippines \\
\hline \multirow[t]{2}{*}{ C } & Coefficient & 0,031612 & $-0,004202$ & 0,053372 & 0,055837 & 0,037207 \\
\hline & prob. & 0,1177 & 0,5778 & 0 & 0,0356 & 0,0733 \\
\hline \multirow[t]{2}{*}{ D_Regionalism } & Coefficient & $-0,049481$ & 0,039983 & $-0,069212$ & $-0,045794$ & $-0,067229$ \\
\hline & prob. & 0,2287 & 0,0166 & 0 & 0,2867 & 0,0441 \\
\hline \multirow{2}{*}{$\begin{array}{l}\text { D_Open Re- } \\
\text { gionalism }\end{array}$} & Coefficient & $-0,013573$ & $-0,082192$ & $-0,043271$ & 0,010604 & 0,009776 \\
\hline & prob. & 0,7026 & 0,0017 & 0,0012 & 0,8253 & 0,8279 \\
\hline \multirow[t]{2}{*}{$A R(1)$} & Coefficient & 0,434122 & & 0,738820 & 0,719814 & \\
\hline & prob. & 0,0635 & & 0.0007 & 0,0001 & \\
\hline \multirow[t]{2}{*}{$A R(2)$} & Coefficient & & & $-0,422866$ & & \\
\hline & prob. & & & 0,0349 & & \\
\hline \multirow[t]{2}{*}{ MA(1) } & Coefficient & $-0,997266$ & $-0,997455$ & $-0,997241$ & $-1,4696420$ & \\
\hline & prob. & 0,0007 & 0,0000 & 0,0000 & 0,0000 & \\
\hline R-squared & Coefficient & 0,373283 & 0,504052 & 0,576512 & 0,594707 & 0,143238 \\
\hline \multirow[t]{2}{*}{ F-stat } & Coefficient & 4,0120419 & 9,824629 & 6,806723 & 9,904625 & 2,0507784 \\
\hline & prob. & 0,011001 & 0,000124 & 0,000394 & 0,000046 & 0,09379 \\
\hline
\end{tabular}

\section{Singapore}

As said before, membership to ASEAN as a regional cooperation should benefit its members' exports as it discriminates non-members in its trading. It is found that the probability value of Singapore's regionalism shows that it has a significant effect on Singapore's exports. It can be said from this result that Singapore's exports are affected positively compared to when only multilaterals regime existed, or when the regional regime (AFTA) was not yet fully effective. It could be said that Singapore's high export values compared to its fellow ASEAN members shows that its exports are very competitive in the region. Therefore, Singapore would not be a disadvantaged country. This also shows that Singapore has strong trading status among the ASEAN member countries, where Singapore might have certain commodities in which it gives Singapore the status of absolute advantage in trading.

Open regionalism shows to have a significant effect to Singapore's exports from the probability value seen in the table above. Its relationship is shown to be negative due to the negative coefficient value. This indicates that compared to the previous international cooper- 
ation regimes, Singapore's export is not benefitted from open regionalism. This may be due to Singapore's long history of their openness of trade, in which being a very open country the membership of APEC wouldn't give higher benefits for the country. The negative value of the coefficient might indicate that Singapore's membership to APEC made trading competition higher for Singapore, competing with many of the world's most advanced countries.

\section{Malaysia}

The probability value of the coefficient of the regionalism dummy variable in Malaysia shows that regionalism has a highly significant relationship to the country's exports. Regionalism's coefficient value shows that it has a significant negative relationship to the country's exports. This shows that the fully effective AFTA is not as benefitting compared to the multilateral regime or even to the years of when AFTA was not yet fully effective. In other ASEAN-5 markets, Malaysia's export has to compete with all other ASEAN members' export that are more competitive. The coefficient of open regionalism dummy variable is also significant and has a negative sign. It can be said that for Malaysia that its membership to APEC does not benefit its exports, in other words it means Malaysia's exports became lower after APEC has become fully effective for the developed member countries. This may happen due to lack of competitiveness of malaysia's export in APEC members' markets.

\section{Thailand}

Regionalism shows to have no significant effect on Thailand's exports. This means that by the time AFTA has become fully effective the export in Thailand is less benefitted compared to the multilateral regime and when AFTA has not yet become fully effective. The presence of other more open ASEAN-5 markets also means that Thailand's export has to compete with other lower labor costs countries such as Vietnam, Cambodia, Laos and Myanmar. Open regionalism is shown to have an insignificant effect on Thailand's export seen from the probability results. In open regionalism, lower tariffs given to Thailand and other APEC members are also given to other non-APEC trading partners in more developed APEC markets. The fact that this does not significantly reduce Thailand's export as formerly thought, could be due to Thailand's export are different from other APEC trading partners' export.

\section{Philippines}

Regionalism seems to have a significant effect towards Philippines' exports looking at the value of the regionalism dummy variable's probability in the table above. The sign is negative, which means that the Philippines' export declined after AFTA became fully effective. Lower or zero tariffs in ASEAN-5 countries means that these markets are also accessible by lower labor cost countries such as the CLMV countries, especially Vietnam. The negative sign and significant effect could be due to lower competitiveness of the Philippines' export compared to those of the CLMV's. Like in Thailand and Indonesia, the coefficient of open regionalism dummy variable is not significant. This could be due to the Philippines' export are different from developed APEC members trading partners' so that open regionalism does not change the Philippine export significantly.

\section{Conclusion}

This study examines the effect of regionalism (after AFTA has become fully effective in 2002) and open regionalism (after APEC was fully effective for its developed member countries in 2010), compared to the effect of multilateralism (when WTO mainly rules were applied on period 1980-2002). The results are as follows: 
1. Regionalism for the ASEAN-5 members reached through a fully effective AFTA by the end year of 2002 is shown to be not very effective in boosting the countries' exports. Indonesia and Thailand's exports did not experience a significant impact from regionalism, whereas Malaysia and The Philippines' exports experienced a significant negative impact from regionalism. Singapore was the only country in which its exports were benefitted from a fully effective AFTA. This may be due to the country's long history of a very open trading policy and a fully effective AFTA boosts its already high trading competitiveness.

2. As seen by the results, it can be summarized that most ASEAN-5 countries do not gain from the establishment of open regionalism through APEC membership. It is seen that for Indonesia, Thailand, and Philippines that open regionalism does not give a significant impact on their exports. Singapore and Malaysia's exports appear to be significantly affected by APEC, although negatively where their exports have become lower after APEC has become fully effective for the developed member countries. Therefore, these results indicate that overall, the ASEAN-5's membership in APEC does not benefit or improve their exports at a significant level.

3. To conclude, among the ASEAN-5 countries, only Singapore which has long been known as a very open country in trade, benefits from AFTA. APEC as an open regional trading agreement does not improve any of the 5 ASEAN countries' export. From these results it can also be stated that economically speaking, most of the ASEAN-5 countries are more benefitted from multilateralism, or prior to the year when AFTA and APEC were fully effective. So, according to the findings in this study, trading-wise it does not benefit most of the ASEAN-5 countries to join an international cooperation as exports does not seem to be affected significantly. These results do not signify that the ASEAN-5 countries should in the future decide not to participate or agree to another international cooperation, as international cooperation memberships for a nation is of importance in many other aspects. This study proves that some of the major trading agreements that the ASEAN-5 countries has been participating in does not necessarily benefit exports as stated in the goals of each respective international cooperation.

\section{References}

APEC. (2016). Achievements and benefits Extracted from: http://www.apec.org/About-Us/ About-APEC/Achievements\%20and\%20Benefits.aspx

Arcas, R. L. (2011). Proliferation of regional trade agreements: complementing or supplanting multilateralism? Chicago Journal of International Law, 11(2).

de Azevedo, A. F. Z. (2002). What Has Been the Real Effect of Mercosur on Trade: A Gravity Model Approach. Universidade Federal do Rio Grande do Sul, Programa de Pos-Graduação em Economia.

Garnaut, R. (2004). A New Open Regionalism in The Asia Pacific. Research School of Pacific and Asian Studies, The Australian National University.

Hastiadi, F. (2011). Regionalism in East Asia: The Role of North East Asian Nations. American Journal of Eonomics and Business Administration, 3(2).

Hormats, R. D. (1994). Making Regionalism Safe. Council on Foreign Relations. New York.

Jayanthakumaran, K., \& Sanidas, E. (2007). The Complementary Hypothesis of Integration: Regionalism, Multilateralism and The ASEAN-5. Asia Pacific Journal of Economics \& 
Business, 11(1).

López, P. P. (1994). The impact of trade liberalisation on exports, imports, the balance of payments and gowth: the case of mexico. Department of Economics, University of Kent.

Park, S. H. (2002). The New Economy and APEC Capacity Building. Pacific Economic Papers, 323.

Romalis, J. (2004). NAFTA's and CUFSTA's Impact on International Trade. University of Chicago GSB and NBER.

World Bank (2015). Export of Goods and Services (\% of GDP). Extracted from: http://data. worldbank.org/indicator/NE.EXP.GNFS.ZS

WTO (2015). What we stand for. Extracted from: https://www.wto.org/english/thewto_e/ whatis_e/what_stand_for_e.htm 